\title{
Protecting Product Designs through Design Patents and Copyright Law in China
}

\author{
Wenting Huang1,2 \\ ${ }^{1}$ School of Law, Yantai University, Yantai, China \\ ${ }^{2}$ Maurer School of Law, Indiana University, Bloomington, USA \\ Email: whuang254@hotmail.com
}

How to cite this paper: Huang, W. T. (2021). Protecting Product Designs through Design Patents and Copyright Law in China. Beijing Law Review, 12, 888-905. https://doi.org/10.4236/blr.2021.123045

Received: August 2, 2021

Accepted: September 7, 2021

Published: September 10, 2021

Copyright $\odot 2021$ by author(s) and Scientific Research Publishing Inc. This work is licensed under the Creative Commons Attribution International License (CC BY 4.0).

http://creativecommons.org/licenses/by/4.0/

\begin{abstract}
This paper argues that a designer with product designs in China, should obtain multiple protections through the intellectual property rights and related laws. This paper focuses on a specific aspect of Chinese intellectual property law related to design protection: design patents and copyright law. It aims to introduce the current legal framework of the Chinese Patent Law and Copyright Law and highlight the different standards in the protection of design patents, artistic works and works of applied art through real cases. Additionally, the paper evaluates and compares design patent protection and copyright protection in various areas, such as protectable subject matter, terms of protection, and infringement determination. This paper also explains that dual protection for a single product design is reasonable under both the Patent Law and Copyright because no evidence shows that Chinese law prohibits such protection. Ultimately, the Anti-Unfair Competition Law is likely to offer residual protection for product designs with "well-known" status. Therefore, the multiple protections provided by design patents, copyright law and unfair competition law are justified.
\end{abstract}

\section{Keywords}

Chinese Law, Design Patent, Copyright, Works of Applied Art, Anti-Unfair Competition

\section{Introduction}

Product design is playing an increasingly important role in the worldwide commercial market. A well-designed product is more likely to attract consumers' attention with its visual appeal and fashionable appearance. As Chinese consumers generally prefer well-designed products, the design industry is booming in Chi- 
na. China has emerged as a global manufacturing hub and a maturing consumer market. However, with new opportunities, risks arise for design businesses in the Chinese market. One of the greatest challenges is copycatting. Although Chinese law offers protection for designers against fake or counterfeit products, many gray areas concerning design protection exist in Chinese law.

Product design consists of imagining and creating articles meant for mass production. It includes not only the aesthetic physical object but also its functional parts ${ }^{1}$. Product design is able to create a new product for a business to sell to its customers ${ }^{2}$. The global design industry has been flourishing and evolving in recent years, especially in emerging markets in China. As Chinese consumers have increased spending power, China became the world's largest product market in 2019. In 2020, the Chinese product industry continued to contribute more revenue than any other industry, over $\$ 284$ million $^{3}$.

The legal system in China provides multiple venues for securing product design protection. A product design could potentially be protected by a trademark, by trade dress, by a design patent, by copyright, and by the Anti-Unfair Competition Law. Design patents are the most common means of protecting product designs and especially make sense for short lifespan products. However, a design patent requires the registration to be protected, and the patent holder enjoys only fifteen years of exclusive rights. In contrast, the Copyright Law offers a longer protection period than the design patent; copyright applies immediately after the design is used to create a tangible work. Although copyright protection has certain benefits, it has an ambiguous scope for product designs because works of applied art are not covered under the Copyright Law. Most courts treat works of applied art like works of fine art. As both the Copyright Law and the design patent have certain limitations with respect to the protection of product designs, the dual protection existing under the Copyright Law and the Patent Law is justified. In addition to copyright protection and design patent protection, the Anti-Unfair Competition Law can provide residual protection for a product design that has achieved "well-known" status.

This article focuses on the design patent and copyright protection of product designs in China. Section II introduces the design patent protection. This section addresses the protectable subject matter under the design patent, the infringement test through typical cases, and the amended provisions on the design patent. Section III describes the copyright protection for works of applied art and details the court's approach to decisions on works of applied art. Section IV indicates both the benefits and limitations of product design protection through the design patent and the Copyright Law. Section V recommends that product designers consider combined intellectual property protections to protect their ${ }^{1}$ What is Product Design? https://www.strate.education/gallery/news/product-design-definition Accessed 9 April 2021.

${ }^{2}$ What is Product Design? https://newschoolarch.edu/blog/what-is-product-design/ Accessed 9 April 2021.

${ }^{3}$ Facts on the Apparel market in the U.S.,

https://www.statista.com/topics/965/apparel-market-in-the-us/ Accessed 9 April 2021. 
product designs.

\section{Design Patent Protection}

In China, design patents are frequently used in the product designs (Graneris, 2019). A design patent protects the product's shape, pattern, color, or the combination. It does not cover a product's manufacturing process or inner workings (Matthew, 2017). Luxury handbags, the distinctive cut of clothing, the appearance of bottles, the shape of automobiles, decorative and unique lipsticks, fancy shoes, fashionable pieces of furniture, household products or even industrial equipment can be protected by a design patent (Paolo, 2021). To be valid, the design must be novel, aesthetically appealing and fit for industrial application ${ }^{4}$.

The design patent in China is protected along with the invention patent and the utility model patent under the Patent Law. However, it is distinguishable from the invention patent and the utility model patent (Moga, 2012). The invention patent protects the method, technical proposals, or the improvement concerning the product or process". The utility model patent is known as "small invention patent" and it covers the technical scheme for the shape, mechanical structure, or the combination of products ${ }^{6}$. Design patents can acquire quickly and cover a broad range of products, while invention patents and utility model patents are more expensive to apply for and requires a longer examination period. Thus, applicants in China are more likely to prefer design patents over invention patents and utility model patents (Graneris, 2019).

\subsection{Legal Framework}

The design patent was first introduced in China in 1984 and was protected as one type of patents under the first version of the Chinese Patent Law (Timoteo, 2010). Only a registered patent design can obtain protection in $\mathrm{China}^{7}$. For a design patent application, the Chinese Patent Office will not conduct a substantive examination to search for prior designs or conflicting applications, and only a formality examination is required ${ }^{8}$. The formality examination investigates whether the application was in accordance with regulations (Chris, 2013). The design patent is published and granted after the formality examination is passed, a process that usually takes three to six months?

\footnotetext{
${ }^{4}$ Art. 2(4) of Patent Law of the People's Republic of China, 17 October 2021; Patents and Designs in China (2020),

https://www.ipaustralia.gov.au/understanding-ip/taking-your-ip-global/ip-protection-china/patents -and-designs-china Accessed 19 June 2021; Rose X Multiple Protection Is Not Redundant for Product Designs (Oct. 10, 2017)

https://niuyie.com/multiple-protection-is-not-redundant-for-product-designs/ Accessed 19 June 2021.

${ }^{5}$ (Art. 2(1) of the Patent Law of the People's Republic of China) 17 October 2021.

${ }^{6}$ (Art. 2(2) of the Patent Law of the People's Republic of China) 17 October 2021.

${ }^{7}$ (Art. 29 of Patent Law of the People's Republic of China) 17 October 2020.

${ }^{8}$ (Art. 27 of Patent Law of the People's Republic of China) 17 October 2020.

${ }^{9}$ Patents and Designs in China (2020),

https://www.ipaustralia.gov.au/understanding-ip/taking-your-ip-global/ip-protection-china/patents -and-designs-china Accessed 19 June 2021.
} 
On October 17, 2020, China promulgated the fourth amendment to the Patent Law to keep pace with developed international practices in the patent world such as those in the United States and Europe. The new Patent Law has come into effect on June 1, 2021. The amendment codifies detailed and significant changes to the design patent through the introduction of partial designs and 15-year design patent protection ${ }^{10}$.

Before this latest amendment, the Chinese Patent Law did not provide for the granting of patent protection for separate components of a design (partial design). Design patent rights were granted only for the overall shape, pattern, or a combination thereof and for the combination of color, shape, and pattern ${ }^{11}$. For example, the sole of a shoe is not eligible for the design patent application without protection being claimed for the whole shoe design, and the handle of a blender cannot be obtained protection separately from the blender (Paolo, 2021). As a result, an applicant, when applying for a design patent, is obligated to submit a drawing or photograph of the whole product. Although a partial design cannot be claimed independently, it can obtain protection through its relation to the whole product incorporating it. Because the separate component of a complete design is not eligible for design patent protection, the act of copying a portion of a product by simple combination and substitution may not be found to be an infringement unless this part of a design occupies a prominent position in the whole product. The lack of protection for partial designs makes it difficult for patent owners to seek legal protection against the copying of partial designs (Zhang, 2021).

The new Patent Law expands coverage for design patents from the "overall design" to the "partial design". This amendment will allow applicants to enjoy protection of parts of their products. It can also curb the copying of partial designs of products (SIPO, 2021). Nevertheless, this may lead to the proliferation of unchecked junk designs because there is no substantive examination of design patent applications. The validity of registered partial designs may only be challenged post-grant by application to the Re-examination and Invalidation Department of the Patent Office (Bird \& Bird, 2014). This will force legitimate rights holders to increase costs to reduce the risks of theft and trolling litigation ${ }^{12}$.

Additionally, the term of design patent protection was only 10 years from the date of filing before this amendment. The new Patent Law has extended the term of design patent protection from 10 years to 15 years ${ }^{13}$. This is in line with the objective of China joining the Hague system, which offers a minimum of 15 years of protection for industrial designs (Ten Highlights of China's New Patent Law, 2020). The 10-year period was far too short for a rights holder to fully enjoy its executive rights. The patent application process can take an entire year or ${ }^{10}$ Decisions of the Standing Committee of the National People's Congress on Amending the "Patent Law of the People's Republic of China" (Oct. 17, 2020, effective date June 1, 2021), https://baijiahao.baidu.com/s?id=1680820370577141549\&wfr=spider\&for=pc.

${ }^{11}$ (Art. 2(4) of the Patent Law of the People's Republic of China) 17 October 2021. ${ }^{12} \mathrm{Id}$.

${ }^{13}$ (Art. 42 of Patent Law of the People's Republic of China) 17 October 2020. 
sometimes longer. Rights holders may spend a substantial amount of time marketing the design product and establishing their market share. It was particularly unfair and insufficient for designers who had achieved a degree of fame in China, as this reputation was lost along with its economic benefits once the ten years expired (Paolo, 2021).

\subsection{Protectable Subject Matter}

A design patent protects the new design of a product: the overall or partial shape, pattern, color, or a combination thereof that has aesthetic appeal and is suitable for industrial application ${ }^{14}$. A typical example of a product that can be protected under a design patent is a coffee set consisting of coffee cups, a milk pot, a coffee pot, and a sugar bowl (SIPO, 2021).

A design patent involves multiple design elements, including shape, pattern, and color or their combination. For example, instead of having four legs with a flat seat and back, a chair may not have any legs; instead, it may have a rounded bottom like a ball that allows the chair to rock forward and backward. This chair is different from a normal four-legged chair, but it still has the same function (Guide to IRP Protection in China for Furniture Industry, 2021). In addition, textile patterns, wine bottle labels or food wrapping paper that consists of ornamental features could be granted design patent rights. However, design patents do not extend a single color of a product unless it is combined with a shape and/or a pattern (Zhang, 2021). For instance, the arrangement of multiple-colored pieces may be considered as a pattern that can enjoy design patent protection (The Guideline, 2010).

A design patent must be novel ${ }^{15}$. This means that the design must be new and not have been disclosed to the public through sale, advertising, or any other means anywhere in the world before the application is filed in China. If the design was disclosed before the application was filed, the patent could be invalidated $^{16}$. In addition, a design patent protects only the aesthetic features of a product. This means that the patent examiner only refers to the visual sensation of the appearance of the product; the function or technical effect of the product are not taken into consideration (The Guideline, 2010: Section 7.2, Chapter 3). For example, a design patent could protect the external appearance of a hairdryer but not the mechanism that causes air to blow (Understanding and Using China's Design Patent, 2021). The aesthetic appealing is not a high threshold for the patent applicant to satisfy. The product does not have to look "good" to be aesthetic; the product only has to have features that can be observed through a person's eyes alone (The Guideline, 2010: Section 7.2, Chapter 3).

Furthermore, a design patent must be fit for industrial application, i.e., it can

${ }^{14}$ (Art. 2(4) of the Patent Law of the People's Republic of China) 17 October 2021 (the definition has been modified since the fourth amendment of the Chinese Patent Law was issued by the State Council in 2020. Before 2020, "design" in the Patent Law meant any new design of a product's shape, pattern or a combination thereof and the combination of color with the shape or pattern of a product that is aesthetic and is capable of industrial application).

${ }^{15}$ (Art. 2(4) of the Patent Law of the People's Republic of China) 17 October 2021.

${ }^{16}$ (Art. 23 of Patent Law of the People's Republic of China) 17 October 2021. 
be used in industry and may be manufactured in batches (The Guideline, 2010: Section 7.2, Chapter 3). Fixed buildings, bridges, etc., that depend on their specific geographic conditions and cannot be rebuilt elsewhere are not suitable for industrial application ${ }^{17}$. In addition, products such as agricultural products, livestock products, and natural products (a sculpture made with roots) that cannot be produced repeatedly are not industrial applicable ${ }^{18}$.

Besides the novelty, the aesthetic value, and the industrial applicability, the Patent Law stipulates additional requirements to the protectable design patents. Specifically, Article 5(1) of the Chinese Patent Law does not allow the Patent Office to grant patent rights for any product if it is detrimental to the public interest ${ }^{19}$. A design containing drawings or images of violence, crime or pornography or national buildings such as the Tiananmen Gate or the White House are not eligible to acquire design patent rights (Zheng, 2017).

\subsection{Standards to Determine the Infringement}

China has experienced significant growth in the number of design patent applications over the last ten years, and typical infringement cases have proliferated in courts as well (WIPO Statistical Country Profiles, 2021). Nevertheless, some cases remain ambiguous regarding how to determine the similarity between an accused product and the patented product and according to what standard before the court decides that infringement has occurred (Moga, 2012). The most complicated and controversial issue relating to design patent infringement actions is whether there is substantial similarity or not. To ascertain infringement in a specific case, whether the observer should identify each element of the design and then compare the similarities and differences of each element individually or whether the observer should look at the design as a whole and then determine the similarity is disputed (Graneris, 2019).

Product Designers can act against a patent infringer through the administrative enforcement or the judicial proceeding ${ }^{20}$. With respect to administrative approach, the product designer can report the patent infringement to a local intellectual property office, requesting the officer to order the infringer to stop the infringement ${ }^{21}$. But the designer could request a court to enforce the order if the local office refused to protect the designer. Regarding the judicial proceedings, the designer may bring patent infringement lawsuit in a court with jurisdiction, requesting the court to issue an injunction to stop the infringing act or award damages ${ }^{22}$. When an infringement case is in process, the defendant will always file an invalidation before the Patent Re-examination Board. If the case is in the litigation, the court may stay the case and wait for the board's decision concerning the invalidation. After the board has made its decision, the patent owner or ${ }^{17}$ Id.

${ }^{18} \mathrm{Id}$.

${ }^{19}$ (Art. 5(1) of the Patent Law of the People's Republic of China) 17 October 2020.

${ }^{20}$ (Art. 65 of the Patent Law of the People's Republic of China) 17 October 2021.

${ }^{21} \mathrm{Id}$.

${ }^{22}$ Id. 
the infringer may appeal the decision in the court if either party is not satisfied with the decision ${ }^{23}$.

\section{1) "Ordinary Observer Test"}

The test for design patent infringement in China is roughly equivalent to the test for infringement in the United States, which, as expressed in Egyptian Goddess v. Swisa, 2008, is whether an "ordinary observer" familiar with the prior art would be deceived into thinking the accused design was the same as the patent design. The traditional approach to ascertaining design patent infringement in China is adopting this perspective of an "ordinary consumer" familiar with the prior art and focusing on the material part of the patent design (Honda v. Heibei Shuanghuan, 2003). The Patent Examination Guidelines provides that the inquiry of whether two designs are identical or substantially similar should be determined in the eye of an ordinary consumer. If an ordinary consumer views, the distinctions between two products, then the judge will not consider the designs are identical or substantially similar with each other (The Guideline, 2010: Section 4, Chapter 5). This test was confirmed by the Fiat Panda Case.

In the Fiat Panda case, Fiat Auto S.P.A. ("Fiat") applied for a design patent for an automobile with the State Intellectual Property Organization, and that application was approved in 2004. In 2006, Great Wall Motor Company ("GWM") exhibited its vehicle, the "GreatWall Jingling", in a show. Fiat sued GWM for producing a car that bore a striking resemblance to Fiat's automobile design patent. The court ruled that the Fiat automobile was different from the GWM vehicle $^{24}$. In this decision, the court considered the front view of the vehicle as most significant part of the Fiat design (Beldiman and Beconcini, 2015). The court did not consider other relevant features of the design, such as the left view, right view, and rear view of the car, compared to the prior design, referring to only the essential part of the design patent in its comparison (Fiat Auto S.PA v. Great Wall Motors, 2008). In contrast, an Italian court reached a totally different decision for the same litigation. While the Chinese court ruled that no infringement had occurred, the court in Italy held that GWM's vehicle had infringed on Fiat's design patent applied for in the EU because the two designs were identical in terms of the overall look (You, 2013).

There are some drawbacks for the "ordinary consumer" test. The traditional approach to infringement is likely to help the defendant to avoid liability because the court is easily to reach a decision of noninfringement by not looking at the minor changes or differences between the accused product and the patented design. The courts merely compare the material portion of the accused product and the patented product. The defendant could simply add or reshape immaterial features of the product design to differentiate their design from the prior art, even though the overall visual impression of the two designs was substantially similar (Graneris, 2019). By comparing on incomplete designs, as many as infringing product will emerge in the market, which impedes the best interest of 
the patent holder and product designers. In light of considerations above, it is necessary to modify the traditional test and to compare the overall visual feature of two similar product designs.

\section{2) "Overall Visual Effect Test"}

To prevent infringers from avoiding liability by merely changing design features or adding design features to a product, the Supreme Court issued Article 11 of the 2009 Interpretation establishing the "overall visual effect" test for design patent infringement. The Interpretation expands the scope of protection offered by design patents and requires courts to inquire whether an "ordinary consumer" familiar with the prior art and looking at the patented design as a whole would find the two designs confusingly similar ${ }^{25}$. In the Honda v. The Patent Reexamination Board (2010) case, the Supreme Court confirmed the "overall visual effect test" and examined a Chinese company's SUV to decide if it infringed on Honda's patented vehicle. The Court found that ordinary consumers would not be confused by the two design ${ }^{26}$. Although the defendant's SUV closely resembled Honda's CR-V, the court found that remarkable differences in specific features, such as the headlamps and side windows, were sufficient to distinguish between the patented design and the accused design ${ }^{27}$.

There are some benefits for courts to adopt the "overall visual effect test." On the one hand, the judge was not relied upon a single design feature to determine similarity, instead, the judges focused on certain unique features and then considered the overall and comprehensive view of the entire design (Beldiman and Beconcini, 2015). On the other hands, patent holders claim protection of the essential elements of a patented product, and the decision-makers will avoid reaching non-infringement decisions in favor of infringers without comparing overall design between the accused design and the patented design.

\section{3) "Modified Overall Visual Effect Test"}

While the overall visual impression test seems fairer to the patent holder, the test does not consider the functionality of the product or the technical features. Infringers could easily alter the functional part of the product or reshape the inner construction of the design to avoid patent infringement. Accordingly, a modified "overall visual effect test" is needed. The Supreme Court improved the test in Jun Hao case by added a new criterion of examination that was not originally specified by the Interpretation (Paolo, 2014). In this decision, the Supreme Court stated that an add-on to the design is not sufficient to avoid infringement if such an addition is merely a decorative function and does not alter the claimed shape of the design patent ${ }^{28}$.

\footnotetext{
${ }^{25}$ (Judicial Interpretation of the Supreme People's Court on Several Issues Concerning the Application of Law in the Trial of Patent Dispute Cases Fa Si, (2009), No. 21), which came into effect on January 1, 2010.

${ }^{26} \mathrm{Id}$.

${ }^{27} \mathrm{Id}$.

${ }^{28}$ The Supreme People's Court stated the following: "The design characteristic in a design patent that is different from an existing design has a significant influence on the overall visual effect. In cases in which the accused design uses the design characteristic of the patented design, simple replacement of a decorative pattern will not influence the similarity between the two in visual effect".
} 
The justification behind this decision seems to balance the urgency to promote novelty and creativity and the need to inhibit patent infringement. On the one hand, extra design elements have no material impact on the similarity of the visual effect. Infringers could easily avoid liability by simply adding extra design elements to the original (Jun Hao case). On the other hand, a mere color or pattern added to an identical or similar design undermines the goal of the Patent Law to encourage invention and creativity ${ }^{29}$.

\section{Copyright Protection}

Copyright and design patents are different kinds of intellectual property rights; copyright is not a substitute for a design patent. Copyright can add another layer of protection to complement design patent protection. Since the design patent may not be available for all product designs, many rights holders have attempted to protect their works from being copied by claiming copyright.

\subsection{Legal Framework}

In China, works of applied art are available to protect product design. Copyright protection sought two ways to protect works of applied art. The first is to seek the protection under the Berne Convention, to which China signed the treaty as a party since 1992. The second way to enforce the copyright of works of applied art is through the Chinese Copyright Law. But the Copyright Law does not list works of applied art in the categories of copyrightable works. Therefore, judicial rulings have treated works of applied art as works of fine art ("artistic works"), and courts have adopted the idea that works of applied art are works of fine art with functionality (Cozzolino, 2018). Since the Copyright Law is silent on works of applied art and the court tends to treat works of applied art as works of fine art (Wang, 2017), attorneys and legal scholars have proposed amending the Copyright Law to extend copyright subject matter to works of applied $\operatorname{art}^{30}$.

In 2014, the Office of Legislative Affairs of the State Council proposed amendments to the Copyright Law ("the draft") to include works of applied art as a separate type of copyrighted work under Article 5(9). Such protection extends to toys, furniture, ornaments and other two- or three-dimensional artworks possessing both aesthetic and functional value. The draft granted twenty-five years of protection to works of applied art (Vivien \& Ann, 2019). However, the draft has never been passed by the Standing Committee of the National People's Congress (Sofia, 2021). As a result, the new Copyright Law does not protect works of applied art, and courts still treat works of applied art as works of fine $\operatorname{art}^{31}$. est revision to the Copyright Law. The Copyright Law was enacted in 1990 and was amended twice, in 2001 and 2010. The new amendment will take effect on June 1, 2021.
} 


\subsection{Works of Applied Art}

In China, the legal basis of copyright protection for works of applied art comes from the Berne Convention for the Protection of Literary and Artistic Works ("Berne Convention"). The Berne Convention stipulates that works of applied art are a type of literary and artistic work and shall be protected by copyright among the contracting parties ${ }^{32}$. To implement the Berne Convention, the State Council of China issued Regulations for the Implementation of International Copyright Treaties in 1992 (the "1992 Provision"), which granted a 25-year term of protection for "foreign works of applied art" only ${ }^{33}$. Consequently, copyright protection by the Berne Convention is not available for Chinese citizens or domestic businesses.

Other than the 1992 Provision, the term "works of applied art" is not mentioned in any other laws or regulations, including the Copyright Law of China and its implementations (Ding \& Lei, 2012). The only other way to enforce copyright protection of works of applied art is to treat them as works of fine art. This is the current trend in how Chinese courts decide cases on works of applied art. Works of fine art are defined as "two or three-dimensional works created in lines, colors or other medium which impact aesthetic effects, such as paintings, works of calligraphy and sculptures" ${ }^{\prime 3}$. Courts across China have found unique chinaware, OkBaby Ltd. v. Cixi Jiabao Child Product Ltd. (2008) decorative jewelry designs (Shenzhen Tongtaifu Jewelry Co., Ltd. v. Guangzhou Xideer Jewelry Co., Ltd., 2013), furniture arrangements, creative toys, lamp designs and several other types of designs to be works of fine art and thus protected by Chinese Copyright Law.

To benefit from copyright protection, a design must meet certain requirements that have been upheld by the courts. To fall into the category of a work of fine art, the product design must possess (1) originality, (2) reproducibility, and (3) a certain level of artistic or aesthetic value ${ }^{35}$. "Originality" and "reproducibility" are basic standards for all copyrightable works; they are easily to fulfill (Cozzolino, 2018). However, rights holders have often been denied copyright protection for works of fine art just because the design is not artistic or aesthetic enough.

\subsection{Standards to Determine the Artistic or Aesthetic Value}

The Copyright Law and its related Interpretations have never set a uniform standard by which the courts can evaluate the artistic or aesthetic value imparted by a design (Zhao, 2021). Decisions relating to artistic value are quite subjective, and judges mainly refer to past decisions ${ }^{36}$.

\footnotetext{
${ }^{32}$ (Art. 2(1) of the Berne Convention).

${ }^{33}$ (Art. 6 of the Implementation of the International Copyright Treaties in 1992).

${ }^{34}$ (Art. 4(7) of Regulations for the Implementation of the Copyright Law of the People's Republic of China, 2013 Revision).

${ }^{35}$ (Art. 2(7) of Regulations for the Implementation of the Copyright Law of the People's Republic of China, 2013 Revision).

${ }^{36}$ Id.
} 
In OkBaby Ltd. v. Cixi Jiabao Child Product Ltd. (2008), an Italian company claimed that a Chinese company copied its child toilet bowls, and that it should be protected by copyright. The court held that the product was artistic and had aesthetic value because it uniquely incorporated the image of an animal, which made it eligible to be protected as a "work of fine art" under the Copyright $\mathrm{Law}^{37}$. The court held that when comparing the products of both parties, apart from minor differences in specific details, the two products were substantially similar. Consequently, the Chinese company infringed on the Italian company's copyrightable product ${ }^{38}$. While the judge deemed the toilet bowl to be aesthetic, specific standards for adjudging a product to be aesthetic were not provided by the court.

Similarly, in Blumberg Industries, Inc. v. Zhongshan Juguang Lamp Ltd. (2006), the court granted copyright protection to the plaintiff s lamp, as the lamp was designed with a decorative flower pattern that bore artistic value and thus qualified as a work of fine art. Furthermore, the court recognized the set of chinaware qualified as a work of fine art, as it differed from traditional chinaware and was highly original and artistic. However, in the case of Children's chairs, the court held that a component of the chairs was relatively simple in design. The plaintiff s chair is almost the same as other similar components of typical chairs. Therefore, the children's furniture was not sufficiently artistic (Inter Ikea System B.V. v. Taizhou Zhongtian Plastic Ltd., 2008).

While many earlier cases regarding the artistic value were mentioned by courts, the standard used to determine the artistic value of the object in previous cases is unclear. Until 2010, the court established the "basic level of intellectual creativity" as the test for evaluating the artistic or aesthetic quality of a work in the Lego Inc. v. Guangdong Xiao Bailong Toy Ltd. (2010). The lower court ruled that Lego's toy bricks could be protected by copyright as works of applied art. The court held that Lego's toy bricks were independently created by the plaintiff and met the basic level of creativity required by the Copyright Law ${ }^{39}$. The judge stated that the defendant failed to present evidence to prove the pre-existence of an identical or substantially similar design; therefore, it was reasonable to assume that such a design was independently created by Lego and not the result of copying another's intellectual creation ${ }^{40}$. Moreover, the Lego toy brick consists of a certain artistic beauty that meets the basic standard of creativity ${ }^{41}$. Thus, the toy bricks have attained minimum artistic value. The court specified that "the basic level of intellectual creativity is not to require the intellectual achievement to reach a comparatively higher level of the artistic or scientific level of aesthetic value, it only requires the intellectual creation as expressed in the work not to be too low and negligible" ${ }^{32}$. Surprisingly, the Supreme Court reached a completely ${ }^{37} \mathrm{Id}$.

${ }^{38} \mathrm{Id}$.

${ }^{39} \mathrm{Id}$.

${ }^{40} \mathrm{Id}$.

${ }^{41}$ Id.

${ }^{42}$ Id. 
different conclusion and held that Lego's toy bricks do not involve enough aesthetic uniqueness; they are a common design for toy blocks, and accordingly, they do not reach the degree of artistic value needed for copyright protection of works of applied art Min-Shen-Zi No. 1345 (2013).

In contrast, the court treated differently another case of Lego toys and held that the involved products could be protected by copyright. On December 29, 2020, Shanghai High People's Court decided a case involving the imitation of Lego toys ("the 2020 Case"). In this case, the court treated the works of applied art as "artworks" and held that according to related implementations, artworks refer to paintings, calligraphy, sculptures, and other artistically significant flat or three-dimensional plastic artworks composed of lines, colors or other elements ${ }^{43}$. The bricks can be placed in different positions and spliced into multiple artistic shapes. Accordingly, the assembled three-dimensional models belong to the artworks and meet the standard of the artistic value (Shanghai Higher People's Court (2020) Hu Xing Zhong No. 105 Criminal Ruling). Compared with the previous case, the toys are common, and the bricks were themselves of low artistic value, here, the current case strengthen the protection of works of applied art by incorporating more types of works into works of art (Chen, 2021).

\section{Advantages and Disadvantages Concerning Design Patents and Copyright Protection}

For a long time, the copyright protection is not the best solution for product designs because the Copyright Law did not protect works of applied art, and most designers would seek design patent protection (Zhang, 2021). Even though Supreme Court cases and related Interpretations now treat works of applied art as artistic works, the law gives works of applied art a shorter term of protection than that afforded to other artistic works. The term of protection for works of applied art is only twenty-five years from the completion of the work ${ }^{44}$.

Nevertheless, the copyright on works of fine art usually lasts for fifty years if the copyright holder is a business or the author plus another fifty years if the copyright holder is an individual (Kelly, 2018). However, either 25 years or 50 years is much longer than the protection period of the design patent, which is only 15 years from the grant date. Compared with a design patent, copyright protection of a product design has other unique advantages. Regarding the means of obtaining rights, copyright is automatically obtained upon completion of the work, and the copyright holder can acquire the right without filing a copyright registration (Kelly, 2018). However, a design patent must be filed by the applicant and be granted upon preliminary examination by the Patent Office ${ }^{45}$. In addition, it is possible to invalidate a design patent under certain circums${ }^{43}$ (Art. 4(8) of Regulations for the Implementation of the Copyright Law of the People's Republic of China, 2013 Revision).

${ }^{44}$ (Art. 6 of the Regulations for the Implementation of International Copyright Treaties) 25 September 1992).

${ }^{45}$ (Art. 27 of Patent Law of the People's Republic of China) 17 October 2020; (Art. 34 of Patent Law of the People's Republic of China) 17 October 2020. 
tances. In contrast, the invalidation system does not apply to copyrightable works (Kelly, 2018).

There are also some disadvantages to protecting a product design through copyright. In terms of the protected object, a relatively high aesthetic value is required for works of applied art. Although a patented design should be aesthetically appealing, there is no requirement regarding the degree of aesthetic value under the Patent $\mathrm{Law}^{46}$. Moreover, in the case of copyright infringement, only the act of copying and distributing without permission is considered an infringing act, while the acts of offering for sale and importation are not ${ }^{47}$. However, in the case of design patent infringement, infringing acts include a broader range of acts, such as manufacturing, offering to sell, selling, or importing the patented product $^{48}$.

Because copyright and design patents both have certain limitations with respect to the protection of product designs, either one is not sufficient to protect designers' products. Although the protection period allowed by copyright is longer, the design of many products does not meet the minimum artistic level for them to be considered works of applied art, which is the greatest obstacle to a product design receiving copyright protection. Thus, a design patent is still a better option to protect a product design, especially for designs that have a short lifespan. However, the protection period of a design patent is shorter than that afforded by copyright. The patent holder will lose protection after the design patent has expired. Thus, combined protection under both copyright and a design patent may be justified.

\section{Designers Should Select Multiple Intellectual Property Rights to Protect Their Product Designs}

\subsection{Combined Protection under the Design Patent and Copyright Law}

Combined protection is not redundant for product designs (Niu, 2017). Design patents can provide initial protection for product designs because they are commonly used in product industry in China. Then, copyright can offer an additional layer of protection after the design patent has expired ${ }^{49}$. As no evidence shows that China prohibits dual protection of product designs, it is fair to allow a product design from acquiring double protection under the Copyright Law and the Patent Law (Fiona, 2012). Dual protection has been confirmed by the court. In Wuxi Haiyi Sculpting Ltd. v. Li Jiashan (2007), the plaintiff obtained a design patent for its diamond-shaped seal handle in 1998. After the design patent expired, the defendant copied the plaintiff's diamond-shaped product. The plaintiff claimed copyright protection for the expired design patent and sued the defendant for copyright infringement. The court held that the diamond-shaped

$$
\begin{aligned}
& { }^{46} \mathrm{Id} . \\
& { }^{47} \mathrm{Id} . \\
& { }^{48} \mathrm{Id} . \\
& { }^{49} \mathrm{Id} .
\end{aligned}
$$


seal handle met the requirement of reproducibility because the design was a decorative industrial product design that could be mass produced. In addition, the seal handle adopted a unique means of expression in the form of the diamond surface, giving consumers a feeling of clear crystal. The features were deemed to have artistic attributes. Therefore, the plaintiff's diamond-shaped seal handle was protected as a work of applied art even though the prior design patent protection was no longer existed ${ }^{50}$.

\subsection{Protection of Well-Known Product Design through Unfair Competition}

In addition to design patent protection and copyright protection, the Anti-Unfair Competition Law could provide the last resort for product designs after all other forms of protection are not available (Niu, 2016: Protecting Works of Applied Art under Chinese Judicial Practice (II)). To receive unfair competition protection, the designer must prove that the product design is "a unique decoration of a well-known commodity" and that other well-known designs have confused the public $^{51}$. For example, in Shantou City Chenhai District Huada Toy Ltd., v. Pinhu Bei Si Da Children's Car Ltd. (2007), the plaintiff produced and sold a battery-driven toy car and sued the defendant for infringing on the unique decoration of its battery-operated toy car product ("HD-6410"). The court concluded that the HD-6410 produced by the plaintiff was commodity with well-known status ${ }^{\prime 2}$. The court held that the front-lights, streamlined body, handles, shimmering color and tail-wing, as a whole, carried unique features that were only used specifically by the plaintiff in the market; these features made the plaintiff's product the unique decoration of a well-known commodity ${ }^{53}$.

In summary, the design industry changes rapidly; product designs normally have a short season. The first step to protect product designs is to apply for a design patent before marketing them to the public. Through this means, designers can obtain a relatively strong 15 -year patent protection. After the 15 -year patent expires, designers can continue to receive another 25 years or 50 years of protection through copyright. With the dual protection of the design patent and copyright, it would be highly beneficial for designers to protect a well-known design with unique decoration under the Anti-Unfair Competition Law. Through the above multiple protections, designers will be better positioned to protect their product designs.

\section{Conclusion}

The current legal system in China is developing and can secure product design protections in multiple ways. A design patent is the most common option for protecting a product design and covers a broad range of product designs, espe- 
cially for handbags, clothing, bottles, vehicles, shoes, furniture, and home decorations. Although a design patent can cover most designs, the protection period is much shorter than the copyright protection period. The patent holder will lose protection after the design patent expires. Thus, copyright protection is considered another option for protecting product designs. However, China is less likely to protect product designs through copyright protection. Copyright Law, Supreme Court's Interpretations and court decisions have never set clear and uniform standards for the protection of works of applied art. As copyright and design patents both have certain limitations with respect to the protection of product designs, dual protection under both copyright and a design patent may be justified. Design patents can provide initial protection for product designs because this is their typical function in China. Then, copyright can offer an additional layer of protection after the design patent has expired. In addition to the design patent protection and copyright protection, the Anti-Unfair Competition Law could provide the last resort for "well-known" product designs. Accordingly, multiple protections for a single product design are feasible.

\section{Acknowledgements}

I would like to express my sincere and deep gratitude to Professor Leaffer, Indiana University Maurer School of Law, Bloomington, USA. Thanks for supervising me independent research on IP-related topic.

\section{Declarations}

This article comes from my independent research. The research was not financially supported. The author has no conflict of interest to declare. WH designed the study, performed the research, and wrote the manuscript. The article has not been published.

\section{Conflicts of Interest}

The author declares no conflicts of interest regarding the publication of this paper.

\section{References}

Art 6 of Anti-Unfair Competition Law of the People's Republic of China (23 April 2019).

Art. 2(1) of the Berne Convention.

Art. 2(1) of the Patent Law of the People's Republic of China (17 October 2021).

Art. 2(2) of the Patent Law of the People's Republic of China (17 October 2021).

Art. 2(4) of the Patent Law of the People's Republic of China (17 October 2021).

Art. 2(7) of Regulations for the Implementation of the Copyright Law of the People's Republic of China (2013 Revision).

Art. 23 of Patent Law of the People's Republic of China (17 October 2021).

Art. 27 of Patent Law of the People's Republic of China (17 October 2020).

Art. 29 of Patent Law of the People's Republic of China (17 October 2020). 
Art. 4(7) of Regulations for the Implementation of the Copyright Law of the People's Republic of China (2013 Revision).

Art. 4(8) of Regulations for the Implementation of the Copyright Law of the People's Republic of China (2013 Revision).

Art. 42 of Patent Law of the People's Republic of China (17 October 2020).

Art. 5(1) of the Patent Law of the People's Republic of China (17 October 2020).

Art. 6 of the Implementation of the International Copyright Treaties in 1992.

Art. 6 of the Regulations for the Implementation of International Copyright Treaties (25 September 1992).

Art. 65 of the Patent Law of the People's Republic of China (17 October 2021).

Beldiman, D., \& Beconcini, P. (2015). The Final Impression Counts-Seeking Common Ground in Design Patent Infringement. Journal of the Patent and Trademark Office Society, 97, 551.

Bird \& Bird (May 2014). Intellectual Property \& 3D Product Design in China. https:/assets.publishing.service.gov.uk/government/uploads/system/uploads/attachme nt_data/file/917053/3D_Product_Design_-_IP_in_China_Factsheet.pdf

Blumberg Industries, Inc. v. Zhongshan Juguang Lamp Ltd. (2006). Beijing No. 2 Intermediate Court, No. 17315.

Chen, Y. R. (2021). Can LEGO Toys Be Copyrighted in China, China Justice Observer. https://www.chinajusticeobserver.com/a/can-lego-toys-be-copyrighted-in-china

Chris, N. (2013). Design Patent in China: Applications, Infringement and Enforcement. https://www.ipwatchdog.com/2013/05/07/design-patents-in-china-applications-infring ement-and-enforcement/id=40026/

Cozzolino, F. (2018). The Protection of Industrial Design as Works of Applied Art in Italy and China: The Case of Ikea Systems b.v. v. Taizhou Zhongtian Plastic Co., Ltd. Universita Ca Foscari Venezia, Venice, Italy.

Ding, X. J., \& Lei, S. Y. T. (2012). Protecting Works of Applied Art under Chinese Judicial Practice (I).

https://niuyie.com/protecting-of-works-of-applied-art-under-chinese-judicial-practicei/

Egyptian Goddess v. Swisa. 543 F.3d 665 (Fed. Cir. 2008).

Fiat Auto S.PA v. Great Wall Motors (2008). Hebei High Court No. 84, 2008.

Fiona, G. (2012). Protection of Works of Applied Art in China, China Intellectual Property. http://www.chinaipmagazine.com/en/journal-show.asp?id=805

Graneris, A. (2019). Protection of Design Patents in China and Comparison with European Union Laws: How Foreign Companies Can Protect Their Design Patents in China. Beijing Law Review, 10, 222. https://doi.org/10.4236/blr.2019.101013

Guide to IRP Protection in China for Furniture Industry (2021). https://www.china-iprhelpdesk.eu/sites/all/docs/publications/Guide_to_IPR_Protectio n_in_China_for_The_Furniture_Industry.pdf

Honda v. Heibei Shuanghuan (2003). Beijing High People's Court.

Honda v. The Patent Reexamination Board (2010). Supreme People's Court.

Inter Ikea Systems B.V. v. Taizhou Zhongtian Plastic Ltd. (2008). Shanghai No. 2 Intermediate Court, No. 187.

Kelly, L. (2018). Copyright Protection on Works of Applied Art. http://www.law-wei.com/en/publish/paper/20180830/231.html

Lego Inc. v. Guangdong Xiao Bailong Toy Ltd. (2010). Beijing No.1 Intermediate Court, 
No. 16676.

Matthew, D. (2017). The ABCs of China Design Patents. https://harrisbricken.com/chinalawblog/the-abcs-of-china-design-patents/

Min-Shen-Zi No. 1345 (2013). The Supreme People's Court of China.

Moga, T. T. (2012). Obtaining and Enforcing Design Patents in China. China Business Review, 39, 28-31. https://doi.org/10.1093/acprof:oso/9780199840687.003.0009

Niu, Y. (2016). Protecting Works of Applied Art under Chinese Judicial Practice (II). https://niuyie.com/protecting-of-works-of-applied-art-under-chinese-judicial-practiceii/

Niu, Y. (2017). Multiple Protection Is Not Redundant for Product Designs. https://niuyie.com/multiple-protection-is-not-redundant-for-product-designs/

OKBaby Ltd. v. Cixi Jiabao Child Product Ltd. (2008). Beijing No. 2 Intermediate Court, No. 12293.

Paolo, B. (2014). China: Enforcement of Design Patents in China in Light of the Latest Jurisprudential Elaborations the Latest Draft Interpretation to the New Patent Law by the Supreme People's Court.

https://www.mondaq.com/china/patent/357188/enforcement-of-design-patents-in-chi na-in-light-of-the-latest-jurisprudential-elaborations-the-latest-draft-interpretation-tothe-new-patent-law-by-the-supreme-peoples-court

Paolo, B. (2021). The China IP Blog Series: The Latest Amendments to the Chinese Patent Law, UIC Review of Intellectual Property Law.

https://ripl.jmls.uic.edu/2021/01/29/the-latest-amendments-to-the-chinese-patent-law/

Patents and Designs in China (2020).

https://www.ipaustralia.gov.au/understanding-ip/taking-your-ip-global/ip-protection-c hina/patents-and-designs-china

Rose X Multiple Protection Is Not Redundant for Product Designs (Oct. 10, 2017). https://niuyie.com/multiple-protection-is-not-redundant-for-product-designs/

Shanghai Higher People's Court (2020). Hu Xing Zhong No. 105 Criminal Ruling.

Shantou City Chenhai District Huada Toy Ltd., v. Pinhu Bei Si Da Children's Car Ltd. (2007). Jiaxin Intermediate Court, No. 12.

Shenzhen Tongtaifu Jewelry Co., Ltd. v. Guangzhou Xideer Jewelry Co., Ltd. (2013). Guangzhou Yuexiu District People’s Court No. 204.

SIPO (2021). Explanations of Opinions on the Draft Amendment to the Implementing Regulations of the Patent Law of the People's Republic of China. http://www.sipo.gov.cn/ztzl/ywzt/zlfjqssxzdscxg/201504/t201514011095942.html

Sofia, B. (2021). China's Copyright Law Amended: Key Changes. https://www.china-briefing.com/news/china-copyright-law-amended-key-changes/

Ten Highlights of China's New Patent Law (Oct. 21, 2020). https://gowlingwlg.com/en/insights-resources/articles/2020/ten-highlights-of-china-snew-patent-law/

The Guideline 2010 Section 4, Chapter 5 (21 January 2010).

Timoteo, M. (2010). La Difesa di Marchi e Brevetti in Cina, Percorsi Normative in un Sistema in Transizione, Giappichelli, Turin, Italy.

Understanding and Using China’s Design Patent (2021). https://www.china-iprhelpdesk.eu/sites/all/docs/publications/China_IPR_SME_Helpde sk-Design_Patent_Guide.pdf

Vivien, C., \& Ann, X. (2019). China Updates Approach to Copyright Protection, Managing IP. 
https://www.managingip.com/article/b1kblzpcckmtsj/china-updates-approach-to-copy right-protection

Wang, X. B. (2017). Protecting Works of Applied Art: Progress and Uncertainty. https://www.managingip.com/article/b1kbpjvw6sgwkx/protecting-works-of-applied-ar t-progress-and-uncertainty

WIPO Statistical Country Profiles (2021).

https://www.wipo.int/ipstats/en/statistics/country_profile/profile.jsp?code=CN

Wuxi Haiyi Sculpting Ltd v. Li Jiashan (2007). Jiangsu High Court, No. 115.

You, Y. T. (2013). Analysis over the Patented Design Dispute between Fiat and GWM in China.

http://www.chinaiplawyer.com/analysis-patented-design-dispute-fiat-gwm-china/

Zhang, W. J. (2021). Harmonization between Copyright Protection and Design Patent Protection in China.

https://www.wto.org/english/tratop_e/trips_e/colloquium_papers_e/2017_asian/chapte r_14_2017_e.pdf

Zhao, T. T. (2021). Copyright Protection for Works of Applied Art in China. https://www.google.com/url? sa =t\&rct=j\&q=\&esrc=s\&source=web\&cd=\&ved=2ahUKE wiikbKPjN7vAhUFG80KHUkLCfIQFjACegQIAxAD\&url=https\%3A\%2F\%2Fdirectory .intellectualpropertymagazine.com\%2Fipwo\%2Ffileserve.htm\%3Fdircode\%3D1\%26file \%3DSep-2015\%252F16\%252FCOPYRIGHT\%2BPROTECTION\%2BFOR\%2BWORKS \%2BOF\%2BAPPLIED\%2BART.pdf\&usg=AOvVaw2IxDp6hCidr4_uftg50TQ9

Zheng, J. H. (2017). Protecting and Enforcing Design Rights: China. https://www.worldtrademarkreview.com/portfolio-management/protecting-and-enforc ing-design-rights-china 